\title{
Journalistic investigations and cabinet crises in the Third Polish Republic (selected examples)
}

\author{
Public opinion, whatever it could be, \\ is extremely powerful. It can overthrow governments, \\ even an undemocratic regime.
}

Karl R. Popper ${ }^{1}$

\begin{abstract}
This article focuses on the influence of investigative journalism on the system of government, and, in particular, on the functioning and break-up of cabinet coalitions in Poland after 1989. It focuses on the parliamentary-cabinet form of government. The source of conflicts which led to the loss of the necessary trust or accelerated the fall of the government were often crises caused by the work of investigative journalists, in which they disclosed facts uncomfortable for members of the Council of Ministers, related to them either directly, through their own reprehensible activities, or indirectly, through the activities of their closest associates. The aim of this article is to show that the unmasking of scandals involving members of the government, their associates or politicians and officials from their political base is a catalyst that can generate cabinet crises, including the collapse of the government. Analyses show the impact of scandals revealed during the term of office of four governments, that of Waldemar Pawlak, Leszek Miller, Jarosław Kaczyński and Donald Tusk.
\end{abstract}

Key words: cabinet crisis, journalistic investigations, political scandals

nvestigative journalism is the most frequently quoted example in literature of the mass media carrying out its 'watchdog' function towards the world of politics, public authorities, bureaucrats and businesses. Many researchers treat this form of reporters' work as a synonym of the 'fourth estate,' able to influence not only the minds of the public, but also to effectively shape the actions of politicians. As an important element of political communication and political journalism, so-called 'muckraking' plays a key role in monitoring the activities of authorities, offices, public institutions and politicians. The essence of the role of an investigative journalist is to reveal and publish all manifestations of wrongdoing within an institution, as well as social problems which present a serious threat to the proper functioning of the political system. This type of media activity also influences public opinion, which exerts pressure on the institution, as well as the political system, and, in certain cases, can lead to real changes. As Karl P. Popper claimed, there are two types of institutions; those in which the public is grounded inside

${ }^{1}$ K. R. Popper (1994), Opinia publiczna w świetle zasad liberalizmu, "Studia Polityczne," no. 3, p. 12. 
the institution, or those with the public outside. He placed the mass media in the first of these groups, alongside political parties, societies, universities, the theater or the cinema (Popper, 1994, p. 12). Personnel, legislative and administrative decisions are often the result of a combination of political events initiated by the results of journalistic investigations published in the press. Political crises can occur as the result of 'unmaskings,' often after a short-term political crisis, which can lead to changes, even far-reaching systemic reforms such as amending the constitution or a piece of legislation. In situations such as these, social interests are protected, while the image of public institutions and politicians is negatively impacted. However, the benefits for the system and society prevail over the damage caused by the publication of articles unmasking improper behavior. Thus, in a democratic regime, the free press performs the important function of informally controlling the three types of power (as described by Montesquieu). Alexis de Tocqueville puts it well: "I approve of it from a consideration more of the evils it prevents than of the advantages it ensures" (Tocqueville, 1976, p. 134).

The focus of this article is the influence of investigative journalism on the government, and in particular on the functioning and break-up of cabinet coalitions in Poland after 1989. This connection seems obvious, and is directly related to the effectiveness of the parliamentary-cabinet form of government. The essence of this method of government is the creation of a cabinet with the support of the parliamentary majority, which grants it legitimacy by a vote of confidence. Multi-party parliamentary support in the Sejm is the dominant model in Poland, the only exception being the current parliament, although even in this case it is not entirely true, because the parliamentary caucus under the name United Right (Zjednoczona Prawica) is in fact a coalition of three parties: Law and Justice (Prawo i Sprawiedliwość), Solidarity of Poland (Solidarna Polska) and Poland Together (Polska Razem). Coalitions comprising large numbers of political parties are usually not stable. The divergence of interests and expectations of partners in political coalition causes major problems in the implementation of the program agreed in the coalition agreement, which can be, paradoxically, the reason for the collapse of the government, sometimes even resulting in a motion of censure against its own Council of Ministers (this happened twice in the case of the rule of Hanna Suchocka and Waldemar Pawlak) (Jednaka, 2006, pp. 117-132; Sokół, 2006, pp. 133-158). The source of conflicts leading to the loss of necessary trust or accelerating the fall of the government were often crises caused by the work of investigative journalists, in which they disclosed facts uncomfortable for members of the Council of Ministers, related to them either directly, due to their own reprehensible activities, or indirectly, due to the activities of their closest associates.

The aim of the article is to show that investigative journalists' unmasking of scandals involving members of the government, their closest associates or politicians and officials belonging to their political base can act as a catalyst that generates cabinet crises, including the collapse of the Council of Ministers. Therefore, investigative publications can be considered very important, although the scandals that they generate are usually only one of several reasons for the weakening or collapse of the government. The author's aim is to answer several research questions related to the aforementioned issues: What subject of investigative journalism effectively affects the decision-making processes leading to cabinet crises and possible change of government? Is it possible to show a correlation 
between the number of parties forming the cabinet coalition and the effectiveness of the press in influencing the government's activity by publishing scandals? Is the generation of scandals related to the Council of Ministers by journalists a reliable method of control over the executive? Or is it part of the political struggle in which the media is used by the opposition? These topics are discussed in the context of selected examples of four cabinet coalitions, in chronological order: that of Waldemar Pawlak, Leszek Miller, Jarosław Kaczyński and Donald Tusk. In the analysis of individual cases, microsystem analysis and the decision method were used. The first of these methods enabled the identification of links between the activity of investigative journalists and the actions of decision-makers in the political system, as well as an assessment of the level of journalism's influence on the conduct of the authorities. The decision method, on the other hand, was helpful in the analysis of processes related to key (mainly personal) decisions caused by investigative publications (Chodubski, 1996, pp. 75-81).

$$
* * *
$$

The issue of political crises is relevant to various social sciences - political science, sociology, and economics (Dobry, 1995; Dahrendorf, 2008; Małkiewicz, 2010; Wielecki, 2012; Soroka, 2013; Rychard, Domański, 2010; Jaskiernia, 2013). Many are of the opinion that this term is often abused and used in various contexts. Sometimes even an economic slowdown is named a crisis (Małkiewicz, 2010, p. 11). The etymology of the concept - and thus its meaning - has been described in various ways. Agnieszka Kasińska-Metryka points to the French origin of the term "crisis" from the word "crise," which means a difficult situation with no clear solution (Kasińska-Metryka, 2013, p. 77). The authors of the Lexicon of Politology, however, see the root of this concept in Latin (crisis) and in Greek (krisis), in which the term is synonymous with a crisis, a breakthrough, a decision (Herbut, 1998, pp. 183-184). 'Crisis' can thus be understood as: (1) the collapse of a given system; (2) an interruption of the normal functioning of an institution; or (3) a sudden turn of events. The characteristics of this type of situation are suddenness, unpredictability, the temporal nature of its occurrence and far-reaching consequences for the functioning of the system (Bankowicz, 1999, pp. 119-120). A crisis may eventually make it impossible for an institution concerned to continue functioning. The consequence of such a breakthrough is sometimes a complete change in policy or the way in which it is implemented (Herbut, 1998, pp. 183-184). It is worth emphasizing the positive role of such crises in politics, which can lead to the initiation of reforms which would otherwise be difficult to implement. Among the various forms of crises, two are crucial for the purposes of this article - the cabinet crisis and the parliamentary crisis. Both are crucial for the government, which requires stable and long-lasting support in the parliament. The term 'cabinet crisis' means "the collapse of the government and the opening of the bidding phase and inter-party negotiations aimed at installing a new team," and "parliamentary crisis' should be understood as "the loss of a comfortable majority by the ruling party or the parliamentary coalition, which compromises their ability to continue their current policy agenda" (Herbut, 1998, pp. 183-184). The phenomenon of the crisis in politics is also important for media studies, in particular the study of the effectiveness of investigative journalism (Olędzki, 1989; 
Adamczyk, 2007; idem, 2008, pp. 66-100; Feldstein, 2001; idem, 2006, pp. 105-120; Molotch, Protess, Gordon, 1996; Orren, 1991; Linsky, 1991; Taras, 1993; Protess, Cook, Doppelt, Ettema, Gordon, Leff, Miller, 1991; Baybars-Hawks, 2003; Meyer, Hinchman, 2004). These analyses focus primarily on the causative role of the mass media in triggering crisis situations in institutions of power. Considerations regarding the model of muckraking (also called a model of mobilization, universal mobilization or defense of society), along with its numerous modifications, sub-divided into the truncated muckraking model and the leaping impact model are also helpful in understanding the possible impacts of investigative journalism on the world of politics. This assumes that the content of investigative report evokes a reaction in the recipients of the new information revealed, as a result of which public opinion becomes a catalyst for appropriate reforms (Molotch, Protess, Gordon, 1996, pp. 44-50).

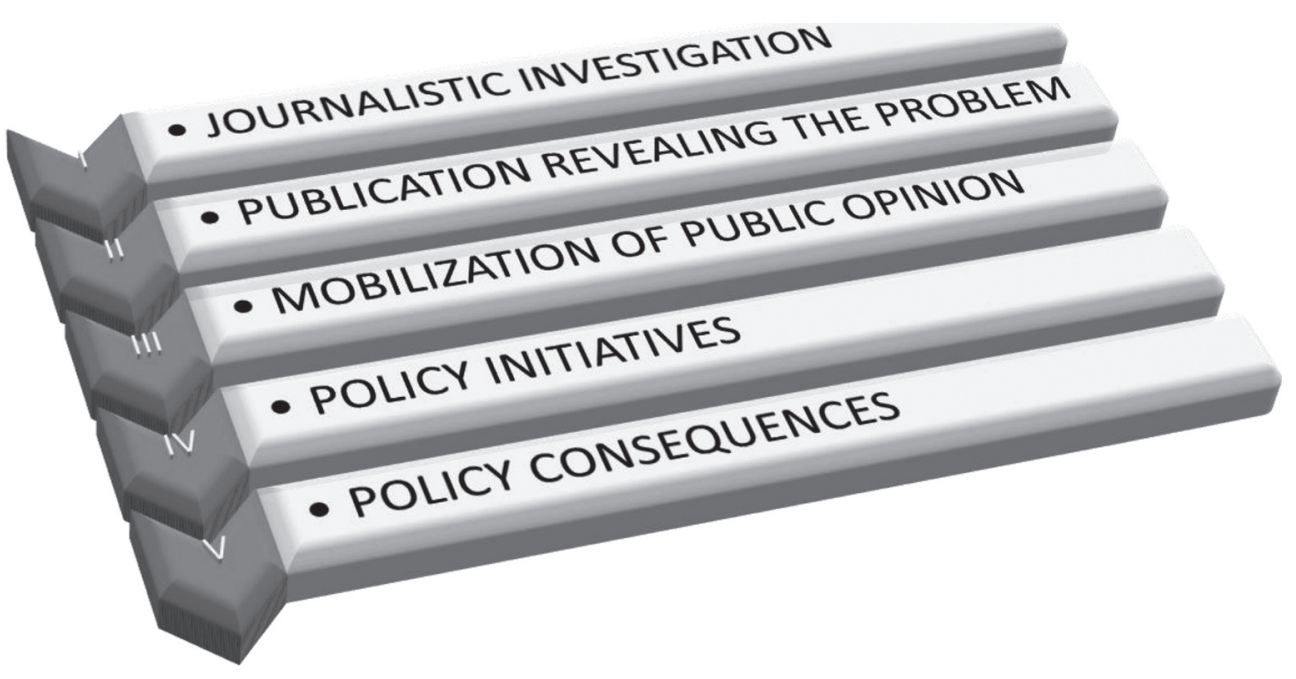

Graph 1. Muckraking model

Source: Own study.

The powerful role of investigative publications in triggering major crises within the executive has been repeatedly analyzed, in particular regarding the best known cases and those which led to changes in key positions. These include the Pentagon Papers and Watergate scandals, which, after being published in "The New York Times" and the "Washington Post" dailies led to the resignation of the President for the first time in US history (Adamczyk, 2008, pp. 85-100). In Europe, the first such high-profile cases in which the power of investigative journalism over the executive was demonstrated were the Profumo scandal in the United Kingdom and events in Germany known as the Spiegel affair. In the first of these cases, journalists published not only the extramarital affairs of the Defense Minister in Her Majesty's government, John Profumo, but also the associated risk of treason in the form of passing information to foreign intelligence, ${ }^{2}$ and his lies in

${ }^{2}$ It was only fifty years after the outbreak of the scandal that Christine Keeler admitted that she had betrayed Britain and forwarded information obtained from Minister J. Profumo to Soviet intelligence agent Yevgeni Ivanov (Millward, 2013). 
the House of Commons. This led first to the resignation of Profumo, and then to a cabinet crisis and the collapse of Harold Macmillan's government in October 1963 (Burgh, 2000, p. 286; Gaster, 1988, pp. 62-88; Thompson, 2000, p. 131-137; Parris, Maguire, 2004, pp. 156-181). In the second scandal, the series of events triggered by articles published in the weekly "Der Spiegel" on the combat readiness of the Bundeswehr after NATO military maneuvers under the code name "Falex 62" led first to a parliamentary crisis which resulted in the exit of one of the parties forming the governing coalition, the FDP, from the government. However, public pressure was so strong that it also forced the resignation of Minister of Defense Franz Josef Strauss who, in the opinion of the Prosecutor General in the lawsuit brought against the weekly, its editors and the author of the publication, acted in a way that was "bordering on illegal" (Kuntz, 1988, pp. 151-154). The dismissals of several ministers from the FDP in November 1962 triggered a cabinet crisis and forced Chancellor Konrad Adenauer to form a new government.

It should be emphasized that investigative journalism serves to make the public aware of the politically and morally reprehensible behavior of politicians. The reporters and the media exercise this form of control primarily by revealing and publicizing cases of inappropriate actions by institutions of power and making the behind-the-scenes activities of the political elite public knowledge. Projects of this type can lead to the disclosure of legal loopholes and other systemic problems which enable corrupt politicians and officials to carry out extralegal activities in order to achieve particular goals. Making public the existence of a "systemic fault" is to stimulate public opinion to put pressure on the political elite and, consequently, reform the activities of political institutions. Initiating these processes in institutions of power has a multifaceted nature. Some may lead to major legislative changes, others to the removal of corrupt politicians and officials from positions of authority. This demonstrates the important role of the mass communication system, along with interpersonal communication, in the system of making political decisions (Kepplinger, 2003, p. 79). Journalists pay special attention to the abuse of power, transgressions by public officials and also to various types of blunders made by people in power. In practice, this means monitoring the activities of the political elite, in particular those carried out in secret. The confidential nature of these activities, in many cases, is driven by the desire to hide unlawful behavior from public opinion, and by the fear of possible sanctions (Blumler, Gurevitch, 1995, pp. 27-29). Contemporary democratic political regimes, accepting the central role of the mass media in shaping public opinion, recognize the right of journalists to uphold the rule of law, to determine the leading themes of public debate and exercise control over those in power (Sartori, 1998, p. 124). The disclosure of scandals involving politicians has the greatest impact on the resources most necessary for governance - reputation and trust. A scandalous public image, in which reprehensible actions are discovered by investigative journalists, leads to social disapproval and sanctions. Scandal in this context is a means to achieve this end, not an end in itself. Its essence is to attract attention and mobilize public opinion to put pressure on the institutions of the political system, which should result in political initiatives and, consequently, decisions aimed at restoring harmony. From this perspective, public opinion becomes a catalyst for the necessary reforms (Molotch, Protess, Gordon, 1996, pp. 44-50). The effects of journalistic investigations observed in the public sphere are: specific reactions of public figures to the issues revealed and publicized by the mass 
media, leading to discussion and the search for solutions (consultative results); sanctions imposed by policy-makers on specific persons or entities responsible for allegedly inappropriate or unlawful behavior (individual results); and changes of a legislative, administrative or control nature (actual reforms) (Baybars-Hawks, 2003). Another effect of publications triggering political scandals are new legal regulations and the introduction of institutional solutions to investigate irregularities in the actions of people in power (Thompson, 2000, p. 114). Put simply, it can be concluded that the mass media have a causative and causal role in the political system, which can be summed up in the statement: "mass communication changes policy" (Schulz, 2006, p. 14).

The issue of the impact of investigative journalism on causing cabinet crises in Poland will be discussed based on the example of four governments (Graph 2).

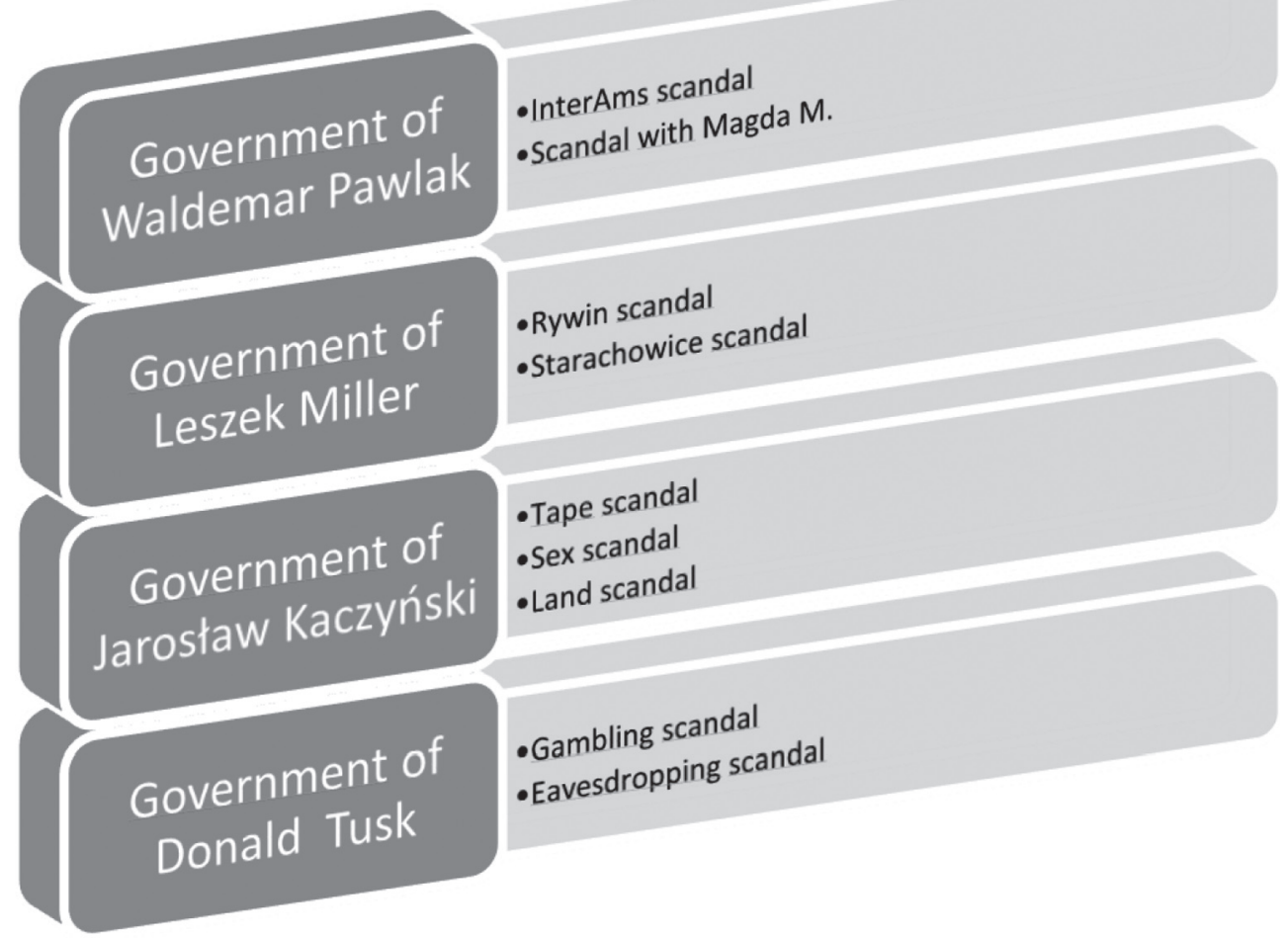

Graph 2. Scandals disclosed by investigative journalists in selected governments of the Third Polish Republic

Source: Own study.

The specificity of the Polish political system, and in particular of the party system, is a useful subject of analysis in this regard. It has been established that "the more the party system deviates from bipartisan, the weaker the government's position towards the parliament, and the more likely cabinet crises are. This is particularly important in Central and Eastern Europe, where party systems are still taking shape, and the political 
scene is both fragmented (with the exception of Albania, Hungary and the Czech Republic) and unstable" (Antoszewski, Herbut, 2007, p. 172). When assessing the durability of governments, one should take into account the number of political parties, the size of the party system, the presence of anti-system parties or other extreme parties which have a destabilizing effect on the duration of the cabinet, the degree of polarization or conflicts related to socio-political divisions and the degree of influence of the opposition in politics (Jednaka, 2004, pp. 53-54). Many reasons for the fall of governments have been described in the literature on the subject. The so-called technical reasons include: regular elections, death or resignation of the Prime Minister and constitutional reasons for the end of the cabinet's term in office. Among the discretionary reasons for the fall of the government, the following have been mentioned: dissolution of the parliament, voluntary extension of the coalition with new political parties, parliamentary failure as a result of opposition activities and conflict between parties or inside the party. Additional catalysts for the resignation of the Cabinet may include personnel, economic, international or national events in the field of security, non-parliamentary events or public opinion (Jednaka, 2004, pp. 67-68; Strøm, Müller, 2000, p. 585).

The coalition government of Waldemar Pawlak (November 10, 1993-March 01, 1995) had the parliamentary support of the Democratic Left Alliance (SLD) and the Polish People's Party (PSL). The two parties formed a coalition with a small majority. Despite a stable parliamentary base, the sustainability of multi-party governments was repeatedly tested. The most serious areas of contention between coalition partners included personnel, agricultural policy, the manner of conducting privatization, foreign policy towards the European Union and Prime Minister Pawlak's style of governing, which is particularly important in the context of the discussed issue of the influence of journalistic investigations on cabinet crises. Pawlak was criticized, among other things, for delays in decision-making, surprising political partners with unexpected changes to previously agreed solutions and a lack of coordination between the government and other authorities. These weaknesses were exploited by the opposition press, which publicized conflicts within the coalition and sought to split the two ruling parties (Sokół, 2006, pp. 154-155). Investigative journalists revealed two scandals. On March 4, 1994, Express Wieczorny accused Prime Minister Waldemar Pawlak of helping his former university classmate, Paweł Zdunek, the owner of the InterAms computer company, to obtain large orders from state-owned companies. Eight months later, on November 20, 1994, the weekly Wprost published an article entitled "Femme fatale of the Prime Minister," which claimed that InterAms owes its success to, inter alia, the fact that it employed the 'supersecretary' Anna M., with whom Pawlak had an extramarital affair (Mistewicz, Witoszek, 1994; Adamczyk, 1999, pp. 146-147; Bereś, 2000, pp. 221-224). On November 28, 1994, the Regional Court in Warsaw declared the bankruptcy of InterAms II. The parties in this case were the company Supra from Poznan and the owner of InterAms II, Paweł Zdunek. At the beginning of December, the Office of the Regional Prosecutor in Warsaw initiated an investigation into the InterAms II company, and a few days later the Supreme Audit Office started to assess the Office of the Council of Ministers. It was tasked with explaining why the Office of the Council of Ministers (URM) chose InterAms without a public tender and whether this was an attempt to rescue a failing company. On March 1, 1995, Prime Minister 
Pawlak resigned, due both to conflicts in the coalition and to accusations against his government in the InterAms case.

Leszek Miller's government (October 19, 2001-May 2, 2004) was created by three political parties: SLD, PSL and Labor United (UP), forming a coalition with a small majority (Sokól, 2006a, p. 24). In this configuration, it survived until March 3, 2003, when the PSL left and the remaining parties ruled as a minority government. Among the important problems for Miller's cabinet was the issue of the so-called Hausner Plan, which divided the UP from the rest of the coalition. As in the case of Pawlak, Prime Minister Miller was criticized for his style of governing, both his way of managing the Council of Ministers and the party. In the latter case, the main challenge was combining the leadership of a political party with the position of the head of government (Michalak, Wincławska, 2006, pp. 253-254). The negative impact on the image of the Cabinet, and hence declining public support, as measured by subsequent public opinion polls, was also connected to scandals publicized by the media. Chronologically, the first scandal to be revealed was the issue of the corrupt proposal submitted by the film producer, Lew Rywin, to the management of Agora and to the Editor-in-Chief of "Gazeta Wyborcza". The matter was referred to in the weekly "Wprost" in September 2002 in the column "From the life of the coalition, from the life of the opposition," a column which is intended to have a light-hearted tone. The content of the proposed agreement focused on the government's changes to the regulations on radio and television that would enable Agora to purchase one of the national television channels. In exchange, Rywin, who claimed to be an informal adviser to Prime Minister Miller, was to demand for himself the position of the head of Polsat television and the amount of 17.5 million dollars, which was to be transferred to the producer's account (Zalewska, 2003, pp. 251-294). On December 27, 2002, "Gazeta Wyborcza" published an article by Paweł Smoleński entitled "Act for a Bribe, or Rywin comes to Michnik," revealing the involvement of Rywin in the corrupt proposal. The opposition took advantage of the public outrage. On January 10, 2003, the Sejm, at the request of the Law and Justice $(P i S)$ and the Civic Platform $(P O)$ parliamentary caucuses, set up a commission of inquiry to investigate the allegations, published in the media, of corruption related to the Radio and Television Act. Three days later, the "Rzeczpospolita" daily published the first results of its own investigation into this case (Majewski, Marszałek, Zalewska, 2003). The commission of inquiry commenced on April 5, 2004. Despite preliminary support for the committee's version of the report prepared by MP Anita Błochowiak, questioning the existence of the mythical 'group holding power,' the decision of the Sejm, taken on September 24, 2004, was the final report prepared by MP Zbigniew Ziobro. This document was radical in its proposals, among others demanding that the Prime Minister and President Aleksander Kwaśniewski appear before the Tribunal of State (Resolution, 2004). On December 10, 2004 , the trial of Lew Rywin was concluded. He was legally recognized as an intermediary for people who wanted to submit a corrupt offer to Agora. The court sentenced him to 2 years in prison and a fine of PLN 100,000 (Gędek, 2015, pp. 116-118).

The second scandal publicized by the media was the 'Starachowice scandal.' In July 2003, "Rzeczpospolita" daily revealed that Andrzej Jagiełł, an MP for the SLD, had warned his party colleague and the governor of Starachowice about an action planned by the Central Investigation Bureau (CBŚ) against members of the gang who cooper- 
ated with local government officials, in a phone conversation in March of the same year. According to the newspaper's findings, Jagiełło was planning to leak information from Zbigniew Sobotka, deputy head of the Ministry of Interior and Administration. To establish the facts, it was necessary to analyze the transcripts obtained by eavesdropping on the governor's phone during the preparations for the action. CBŚ arrested several SLD local government officials. Shortly afterwards, prosecution charges were brought against two SLD deputies - Jagiełło and Henryk Długosz, who mediated in the exchange of information between Sobotka and Jagiełł. In 2005, the District Court in Kielce sentenced Sobotka to 3.5 years, Henryk Długosz to two years, and Andrzej Jagiełło to 1.5 years in prison (Werner, 2013). Both of the above-mentioned scandals contributed to the collapse of the government. On May 2, 2004, Prime Minister Miller handed in his resignation, along with the entire Council of Ministers.

The next case is the government headed by Prime Minister Jarosław Kaczyński, although in this case one should talk rather about three Cabinets. The first was in power from July 19, 2006 until September 22, 2006 and was supported by three parties - Law and Justice, Self-Defense of the Republic of Poland (Samoobrona RP) and the League of Polish Families (LPR). The next Cabinet, without Samoobrona RP, operated from September 22, 2006 until October 16, 2006. The third government, again with the support of Samoobrona RP, governed from October 16, 2006 until August 13, 2007 (Banaś, Lechowicz, 2015, pp. 16-17). The main problems of the cabinets headed by Jarosław Kaczyński were maintaining the coherence of the parliamentary base and dealing with image problems resulting from scandals published by the media about parliamentarians from the ruling parties. In September 2006, Deputy Prime Minister and Minister of Agriculture Andrzej Lepper was dismissed for criticizing budget proposals. This meant weakening the parliamentary base, as members of Samoobrona $R P$ subsequently left the coalition. However, after less than a month, the party returned to the governing coalition. This happened four days before a broadcast entitled "Now WE!" (Teraz MY) was aired on the TV channel TVN. In this broadcast, news that compromised important PiS MPs appeared on recorded video tapes, which began the so-called 'tape scandal.' On the recordings, recorded with a hidden camera, the head of the Prime Minister's Office, Adam Lipiński, urged a member of Samoobrona RP, MP Renata Beger, along with several other Samoobrona RP MPs, to defect to PiS. In return, the minister offered legal assistance to avoid paying off promissory notes with the possibility of using the Sejm's financial resources to fund this, and to have the bailiff called off (these promissory notes were created in order to act as a guarantee in the event that Samoobrona RP MPs left the party during the parliamentary term). The second of the recorded MPs was Wojciech Mojzesowicz, who resigned from the post of Secretary of State in the Office of the Prime Minister on October 26, 2006 (in July the following year he returned to the government as Minister of Agriculture). In March 2007, the prosecutor's office discontinued the proceedings regarding the tape scandal (Tyrała, 2014, p. 117; PAP, 2014).

The next government crisis was related to the so-called 'sexafera' (sex scandal). On December 4, 2006, "Gazeta Wyborcza" published an article entitled Work for sex (Praca za seks) by Marcin Kącki, revealing illicit practices in the Samoobrona RP party, with the participation of prominent activists, in relation to Aneta Krawczyk, a female party activist from the province of Łódź. A day later, in the "Teraz My" program on TVN, Krawczyk 
said that Stanisław Łyżwiński of Samoobrona $R P$ was the father of her three and a halfyear-old daughter, and that his assistant had tried to force her to take an abortion pill (later DNA tests proved that Łyżwiński was in fact not the father). On December 14, Łyżwiński was expelled from the party, and on August 23, 2007, the Sejm denied him parliamentary immunity and thus consented to his arrest. The next day, the prosecutor's office charged Łyżwiński with seven charges, including offering Krawczyk a job in exchange for sexual favors, forcing her and two other women to perform sexual favors, and rape of the district councilor. On November 8, 2007, charges were also leveled against Andrzej Lepper, the leader of Samoobrona $R P$, including demanding and accepting sexual favors from Aneta Krawczyk. In the years 2008-2011, courts convicted several activists of this party in connection with this case, including Łyżwiński and Lepper.

The third of the scandals, known as the 'land scandal,' became a catalyst for the collapse of Jarosław Kaczyński's government. On July 9, 2007, the Minister of Agriculture and the Deputy Prime Minister, Andrzej Lepper, was dismissed from his position in connection with the suspicion that he could have personally benefited from land depreciation. The CBA attempted a provocation handing him a bribe, but they failed. The reason for the failure was a leak, for which the prosecutor's office suspected the head of the Ministry of Interior and Administration, Janusz Kaczmarek, was responsible (on August 8, 2007 he was removed from office). Among those suspected of warning Lepper were the Chief Commander of the Police, Konrad Kornatowski, businessman Ryszard Krauze and an MP for Samoobrona RP, Lech Woszczerowicz. However, the investigation in this case was discontinued. On August 9, 2007, Jarosław Marzec was dismissed by Kaczyński from the post of Central Commandant of the Office of Investigation (he was to be a source of leaks to the head of the Ministry of Interior and Administration). Two days later, the Prime Minister broke the coalition agreement and dismissed ministers from the LPR and Samoobrona RP. On August 23, 2007, PiS filed for the dissolution of the Sejm, which was a consequence of the crisis in the ruling coalition. On September 7, 2007, MPs decided to dissolve the Sejm. Formally, the 'polite' dismissal of the Cabinet took place on November 5.

Donald Tusk twice became the head of the government after parliamentary elections won by his party. The first cabinet formed by PO with PSL support was in office from November 24, 2007 until November 8, 2011, and the second, also in coalition with the PSL, ruled from November 21, 2011 until September 11, 2014. The first cabinet had to face the consequences of the global financial crisis at the beginning of their term of office, which forced the government to implement a restrictive budget policy, in particular in the area of social spending. The opposition also accused the ruling coalition of excessively increasing the state's debt. The Cabinet's image was adversely affected by the decision to raise the retirement age for women and men and to transfer to the Social Insurance Institution (ZUS) savings held in the second pillar (OFE) worth PLN 152.8 billion in 2013. The scandals published by the media were of considerable importance for the coalition and the image of the government. Chronologically, the first was the so-called 'gambling scandal,' revealed on October 1, 2009 by "Rzeczpospolita" (Gmyz, Zawadka, 2009). Politicians from the largest coalition party were involved: the head of the PO caucus, Zbigniew Chlebowski, and the Minister of Sport, Mirosław Drzewiecki. In the article, journalists accused them of lobbying for gambling companies. Referring to the 
findings of the investigation under the name "Black Jack," conducted since March 23, 2009 by the Central Anticorruption Bureau (CBA), "Rzeczpospolita" reporters pointed to two businessmen from the gambling industry, from Lower Silesia - Ryszard Sobiesiak and Jan Koska - who tried to push amendments to the Gambling Act that were beneficial for their companies. Thanks to eavesdropping on telephone conversations, it was established that, at that time, these entrepreneurs had contacted Chlebowski, who headed the Sejm Public Finance Committee, and Drzewiecki, the head of the Ministry of Sport, many times. That office was responsible for preparations for Euro 2012 in Poland. The co-financing of this event came from money obtained from additional taxes (called a surcharge) imposed on gambling companies. This was expected to raise PLN 469 million for the budget. PO politicians declared that they wished to remove the surcharge on gambling companies from the text of the Act. On June 30, 2009, Drzewiecki, in a letter to the Minister of Finance, asked for the surcharge to be removed from the bill, considering their introduction to be "pointless," and applied for "exclusion from further proceedings." On August 12, 2009, the Commander of the Central Anticorruption Bureau informed Prime Minister Tusk of the findings of the investigation. Shortly afterwards, contacts between the businessmen and the politicians ceased, and the CBA informed the Prime Minister of this on September 12, suggesting a leak. On September 18, President Lech Kaczyński was informed about the case. On October 1, 2009, Chlebowski was suspended as the head of the PO parliamentary caucus and announced his resignation as the head of the Public Finance Commission. Four days later, Drzewiecki also resigned. There were more personal consequences related to this scandal. Grzegorz Schetyna, the Deputy Prime Minister and Minister of the Interior and Administration (he became the new chairman of the PO caucus), the Minister of Justice, Andrzej Czuma, and the Deputy Minister of the Economy, Adam Szejnfeld, left the government. Pawel Graś, Sławomir Nowak and Rafał Grupiński concluded their work for the Chancellery of the Prime Minister (the decisions was later revoked in the case of Graś). On October 13, Prime Minister Tusk dismissed Mariusz Kamiński, considering that, in the matter of the 'gambling scandal,' he "used the CBA against political competitors" (Święczkowski, Ziaja, 2014, pp. 99-121; PAP, 2011).

An even more serious image crisis for the next cabinet of PM Tusk was the socalled 'eavesdropping scandal.' On June 14, 2014, fragments of illegal recordings of two eavesdropped conversations in the restaurants Sowa \& Przyjaciele and Amber Room were revealed on the website of the weekly "Wprost". On June 16, transcripts from the recordings were published in the paper edition of the weekly. Among the recorded was the President of the National Bank of Poland and ministers from Tusk's government. On June 18, 2014, the prosecutor's office and the Internal Security Agency (ABW) conducted a search in the editorial office of "Wprost" to obtain media containing recordings of the eavesdropped conversations. On June 22, 2014, the other media began to reveal fragments of the recordings of next conversations between politicians, and a day later "Wprost" published detailed transcripts of these eavesdropped conversations. Under pressure from the opposition demanding the resignation of discredited politicians and officials, on June 25, 2014, Tusk submitted a motion to request a vote of confidence in the Sejm. In the vote, 237 MPs supported the cabinet, 203 were against. However, this did not stop the opposition. The next day, the PiS parliamentary caucus filed a mo- 
tion for a constructive vote of no confidence in the government of Donald Tusk (the candidate for Prime Minister was Professor Piotr Gliński). On July 11, 2014, the Sejm rejected the motions for no confidence votes against the government and the Minister of Internal Affairs. The consequence of the disclosure of the eavesdropped conversations, apart from obvious image problems and decrease in confidence in Tusk's government, was the resignation in September 2014 of Tusk, who became President of the European Council in December. The next cabinet was headed by Ewa Kopacz. On June 10, 2015, the Ministers of Health, Sport, Tourism and the State Treasury, three deputy ministers, Special Services Coordinator and the head of the Political Advisers' Team of the Prime Minister also resigned. Radosław Sikorski resigned from the role of the Sejm Speaker (Latkowski, Majewski, 2014; Wilgocki, 2015).

The analysis of the discussed scandals in four governments proves that, as a result of revelations by journalists, image problems, frictions within coalitions, declining public confidence, dismissals and ultimately the collapse of cabinets are not directly linked to the specific subject matter in press publications. The scandals described in the media concerned a wide range of issues, ranging from corruption, nepotism and sexual exploitation to the embarrassingly low level of illegally overheard conversations between important politicians. Therefore, there is no rule in this area that would indicate the main reason for the emergence of cabinet crises or affecting their severity. A similar conclusion can be reached by analyzing the correlation between the number of parties forming a cabinet coalition and the effectiveness of influencing the government via the media. Of the four described cases, only Miller and Kaczyński had coalitions formed of three political parties, whereas the governments of Pawlak and Tusk were supported by only two parties. Regardless of the number of parties supporting the policy of the Council of Ministers, the scandals revealed by investigative journalists have had similar effects. It is difficult to see the direct influence of the number of coalition partners on the number of scandals and government crises they generate. The only noticeable feature of the cabinets with parliamentary support consisting of two parties is their greater determination in the struggle to survive the crisis and stay in power, also expressed in the visible consolidation of the parliamentary base. In the case of cabinet coalitions supported by three parties, with differing numbers of seats in the parliament and led by a Prime Minister with a strong personality (such as Kaczyński), media scandals can quickly lead to the disintegration of the ruling system, though not necessarily the downfall of the Council of Ministers itself. In all the discussed scandals, the source of exposure was the opposition media. This is of course nothing extraordinary in the context of the control function exercised by the press, which should make journalists independent of the government, irrespective of who is at the helm. Only in this way can the 'fourth estate' fulfill its obligations to the public. However, it is impossible not to notice the significant involvement of the media in favoring specific political groups and publicizing scandals which make it more difficult for their competitors to govern. This is evidenced by the InterAms scandal ("Wprost"), Rywin scandal ("Gazeta Wyborcza"), tape scandal (TVN and "Gazeta Wyborcza"), sex scandal ("Gazeta Wyborcza"), and eavesdropping scandal ("Wprost"). In these cases, investigative publications were used in the political struggle, and the media themselves were treated by the opposition as an instrument to weaken their opponents. 
The described examples of investigative journalism indicate that their publication has a significant impact on the stability of cabinet coalitions in Poland. The disclosed scandals reduced public support for the government and increased the visibility of their actions, thus revealing the weaknesses of both the political parties themselves and the institutions they represent, as well as individual politicians or high-level officials. In this way, the media have the power to deprive governments of the necessary public support and trust that they need to retain power. Although the investigative publications themselves are rarely the only factor in the government's collapse, they can certainly be considered as a catalyst for generating cabinet crises, including the breakdown of the Council of Ministers. Negative public opinion caused by such exposures and the pressure exerted on the institutions of power often translates into direct consequences for the government, ranging from personal and legislative consequences to the loss of the ability to govern effectively.

\section{Bibliography}

Adamczyk W. (2007), Dziennikarstwo śledcze a kryzysy polityczne, in: Media a polityka, eds. A. M. Zarychta, Ł. Donaj, M. Kosiarz, A. Barański, Łódź.

Adamczyk W. (1999), Media masowe w procesie budowania demokracji w Polsce (1989-1995), Poznań.

Adamczyk W. (2008), Amerykańskie archetypy dziennikarstwa śledczego, Poznań.

Antoszewski A., Herbut R. (2007), Systemy polityczne wspótczesnej Europy, PWN.

Banaś M., Lechowicz P. (2015), Kohabitacja a trwatość gabinetów koalicyjnych w Polsce po 1991 roku, "Polityka i Społeczeństwo," no. 4(13).

Bankowicz M. (ed.) (1999), Stownik polityki, Warszawa.

Baybars-Hawks B. (2003), The Impact of Investigative Journalism on Public Opinion and Policymaking, Proc. 1st Int. Hawaii Conference on Arts and Humanities, Hawaii, USA.

Bereś W. (2000), Czwarta władza. Najważniejsze wydarzenia medialne III RP, Warszawa.

Blumler J., Gurevitch M. (1995), The Crisis of Public Communication, London-New York.

Burgh de H. (2000), High politics and low behaviour. The Sunday Times Insight, in: Investigative Journalism. Context and Practice, ed. H. de Burgh, London-New York.

Cepernich C. (2002), Media and Political Scandals in Italy. Mistrust on the Ground of Antipolitics, paper presented during a combined session in the "Antipolitics and the Media" working group, XXIX ECPR, Turin March 22-27, 2002.

Chodubski A. (1996), Wstęp do badań politologicznych, Gdańsk.

Dahrendorf R. (2008), Klasy i konflikt klasowy w społeczeństwie przemysłowym, Kraków.

Dobek-Ostrowska B. (ed.) (2004), Media masowe w systemach demokratycznych. Teoretyczne problemy i praktyczny wymiar komunikowania politycznego, Wrocław.

Dobry M.(1995), Socjologia kryzysów politycznych, Warszawa.

Feldstein M. (2001), Ventriloquist or Dummy? A model of how sources set the investigative agenda, paper submitted to the Communication Theory \& Methodology Division, AEJMC Convention, August.

Feldstein M. (2006), A Muckraking Model: Investigative Reporting Cycles in American History, "The Harvard International Journal of Press/Politics".

Gaster R. (1988), Sex, Spies, and Scandal. The Profumo Affair and British Politics, in: The Politics of Scandal. Power and Process in Liberal Democracies, eds. A. S. Markovits, M. Silverstein, New York-London. 
Gędek M. (2015), Rynek medialny w Polsce. Zarys ewolucji ostatnich czterdziestu lat, Lublin. Gmyz C., Zawadka G. (2009), Wplywowi politycy i afera hazardowa, "Rzeczpospolita," 1.10.2009. Graber D. A. (1984), Mass Media and American Politics, "Congressional Quarterly," Washington. Herbut R. (1998), Kryzys (hasło), in: Leksykon politologii, eds. A. Antoszewski, R. Herbut, Wrocław. Jaskiernia J. (2013), Dostosowanie systemu ustrojowego Rzeczypospolitej Polskiej do działania w warunkach kryzysowych, in: Kryzysy gospodarcze i polityczne a ewolucja systemów politycznych, ed. P. Soroka, Kielce.

Jednaka W. (2004), Gabinety koalicyjne w III RP, Wrocław.

Jednaka W. (2006), Rzad Hanny Suchockiej (11 VII 1993-26 X 1993), in: Rzqdy koalicyjne w III RP, ed. M. Chmaj, Olsztyn.

Kasińska-Metryka A. (2013), Przywództwo polityczne w czasach kryzysu - nowe wyzwania, in: Kryzysy gospodarcze i polityczne a ewolucja systemów politycznych, ed. P. Soroka, Kielce.

Kącki M. (2006), Praca za seks w Samoobronie, "Gazeta Wyborcza,” 4.12.2006.

Kepplinger H. M. (2003), W kierunku systemowej teorii komunikowania politycznego, in: Media masowe $w$ systemach demokratycznych. Teoretyczne problemy i praktyczny wymiar komunikowania politycznego, ed. B. Dobek-Ostrowska, Wrocław.

Kuntz A. (1988), From Spiegel to Flick: The Maturation of the West German Parteienstaat, in: The Politics of Scandal. Power and Process in Liberal Democracies, eds. A. S. Markovits, M. Silverstein, New York-London.

Latkowski S., Majewski M. (2014), Afera podstuchowa. Taśmy ,,Wprost”, Poznań.

Linsky M. (1991), Impact: How the Press Affects Federal Policy Making, New York-London.

Majewski M., Marszałek A., Zalewska L. (2003), W sieci zależności, “Rzeczpospolita," 13.01.2003.

Małkiewicz A. (2010), Kryzys. Polityczne, ekologiczne i ekonomiczne uwarunkowania, Warszawa.

McNair B. (1998), Wprowadzenie do komunikowania politycznego, Poznań.

Meyer T., Hinchman L. (2004), Media Democracy. How the Media Colonize Politics, Cambridge.

Michalak B., Wincławska M. S. (2006), Rzqd Leszka Millera (19 X 2001-2 V 2004), in: Rzqdy koalicyjne w III RP, ed. M. Chmaj, Olsztyn.

Millward D. (2013), Christine Keeler admits she betrayed Britain, "The Telegraph," 9.06.2013 [retrieved: 22.09.2013].

Mistewicz E., Witoszek A. (1994), Femme fatale premiera, "Wprost," 20.11.1994.

Molotch H. L., Protess D. L., Gordon M. T. (1996), The Media-Policy Connection: Ecologies of News, in: Political Communication Research: Approaches, Studies and Assessments, vol. II, ed. D. Paletz, Norwood.

Olędzki J. (1989), Amerykańskie środki przekazu w okresie kryzysów politycznych, "Przekazy i Opinie," no. 3-4.

Orren G. R. (1991), Thinking About the Press and Government, in: M. Linsky, Impact: How the Press Affects Federal Policy Making, New York-London.

PAP (2011), Rzqd Donalda Tuska 2007-2011 (Kalendarium), 16.11.2011, http://forsal.pl/artykuly 1566318,rzad-donalda-tuska-2007-2011-kalendarium.html, 20.11.2011.

PAP (2014), Polityczne podsumowanie najważniejszych wydarzeń 25 lat, 2.06.2014.

Parris M., Maguire K. (2004), Great Parliamentary Scandals. Five Centuries of Calumny, Smear and Innuendo, London.

Piontek D. (2011), Komunikowanie polityczne i kultura popularna. Tabloidyzacja informacji o polityce, Poznań.

Popper K. R. (1994), Opinia publiczna w świetle zasad liberalizmu, "Studia Polityczne," nr 3.

Protess D., Cook F. L., Doppelt J. C., Ettema J. S., Gordon M. T., Leff D. R., Miller P., The Journalism of Outrage. Investigative Reporting and Agenda Building in America, New York-London. 
Resolution of the Sejm of the Republic of Poland of 24 September 2004 on the report of the Investigation Commission to investigate allegations of corruption in the media during work on the amendment of the Radio and Television Act (M.P.).

Rychard A., Domański H. (eds.) (2010), Legitymizacja w Polsce. Nieustajacy kryzys w zmieniajacych się warunkach?, Warszawa.

Sartori G. (1998), Teoria demokracji, transl. P. Amsterdamski, D. Grinberg, Warszawa.

Schulz W. (2006), Komunikacja polityczna. Koncepcje teoretyczne i wyniki badań empirycznych na temat mediów masowych w polityce, Kraków.

Sokół W. (2006), Rzad Waldemara Pawlaka (26 X 1993-1 III 1995), in: Rzqdy koalicyjne w III RP, ed. M. Chmaj, Olsztyn.

Sokół W. (2006a), Teoretyczne aspekty tworzenia i funkcjonowania rzqdów koalicyjnych, in: Rzqdy koalicyjne w III RP, ed. M. Chmaj, Olsztyn.

Soroka P. (ed.) (2013), Kryzysy gospodarcze i polityczne a ewolucja systemów politycznych, Kielce.

Strøm K., Müller W. C. (2000), Coalition Governments in Western Europe, Oxford.

Szybisty Z., Afera hazardowa. O co chodzi?, "Gazeta Wyborcza," 1.10.2009, http://wiadomosci.gazeta. pl/wiadomosci/1,114873,7099027,Afera_hazardowa_O_co_chodzi_html, 3.10.2009.

Święczkowski B., Ziaja Ł. (2014), Afery czasów Donalda Tuska, Poznań 2014.

Taras D. (1993), The Mass Media and Political Crisis: Reporting Canada's Constitutional Struggles, "The Canadian Journal of Communication," vol 18, no. 2.

Thompson J. B. (2000), Political Scandal. Power and Visibility in the Media Age, Polity Press.

Tocqueville de A. (1976), O demokracji w Ameryce, transl. M. Król, PIW.

Tyrała M. (2014), Koalicje polityczne w Polsce w latach 1991-2011, doctoral dissertation, Katowice.

Uchwała Sejmu Rzeczypospolitej Polskiej z dnia 24 września 2004 r. w sprawie sprawozdania Komisji Śledczej do zbadania ujawnionych w mediach zarzutów dotyczacych przypadków korupcji podczas prac nad nowelizacjq ustawy o radiofonii i telewizji, M.P. 2004, $\mathrm{Nr} 41$, poz. 711.

Werner M. (2013), Afera starachowicka: Rzadki przypadek przykładnego osqdzenia sprawców, "Dziennik Gazeta Prawna," 15.02.2013.

Wielecki K. (2012), Kryzys i socjologia, Warszawa.

Wilgocki M. (2015), Afera podsłuchowa. Najważniejsze wydarzenia [Kalendarium], 11.06.2015, http:// wyborcza.pl/1,75398,18098199,Afera_podsluchowa_Najwazniejsze_wydarzenia_KALENDARIUM_html?disableRedirects=true, 15.06.2015.

Zalewska L. (2003), Kalendarium afery, in: System Rywina czyli druga strona III Rzeczypospolitej, ed. J. Skórzyński, Warszawa.

ZSZ, Drzewiecki podaje się do dymisji. Natychmiast, "Gazeta Wyborcza," 5.10.2009, http://wiadomosci.gazeta.pl/wiadomosci/1,114873,7110359,Drzewiecki_podaje_sie_do_dymisji_Natychmiast.html, 7.10.2009.

\section{Śledztwa dziennikarskie a kryzysy gabinetowe w III RP (na wybranych przykładach)}

\section{Streszczenie}

Przedmiotem rozważań jest wpływ dziennikarstwa śledczego na system rządów, a w szczególności na funkcjonowanie i rozpad koalicji gabinetowych w Polsce po 1989 roku. Cezura ta ma bezpośredni związek z ukształtowaniem się w ramach transformacji systemowej parlamentarno-gabinetowej formy sprawowania rządów. Źródłem konfliktów prowadzących do utraty niezbędnego zaufania lub przyspieszających upadek rządu były niejednokrotnie kryzysy wywołane przez publikacje dziennikarzy 
śledczych, w których ujawniali oni fakty niewygodne dla członków Rady Ministrów, związane bezpośrednio z ich nagannymi działaniami lub pośrednio z aktywnością ich najbliższych współpracowników. Celem artykułu jest wykazanie, że demaskowanie przez reporterów dochodzeniowych afer z udziałem członków rządu, ich najbliższych współpracowników lub polityków i urzędników z zaplecza politycznego stanowi swoisty katalizator generujący kryzysy gabinetowe, włącznie z zakończeniem misji Rady Ministrów. Analizie poddano wpływ skandali ujawnionych w czasie misji czterech rządów: W. Pawlaka, L. Millera, J. Kaczyńskiego i D. Tuska.

Słowa kluczowe: kryzys gabinetowy, dziennikarskie śledztwa, afery polityczne 